\title{
Effect of Various External Shading Devices on Windows for Minimum Heat Gain and Adequate Day lighting into Buildings of Hot and Dry Climatic Zone in India
}

\author{
Gorantla Kirankumar $^{1}{ }^{*}$, Shaik Saboor ${ }^{2}$, Putta Ranga Talanki Setty ${ }^{1}$ and Ashok Babu ${ }^{1}$ \\ ${ }^{1}$ Mechanical Engineering Department, National Institute of Technology Karnataka, Surathkal, \\ Mangalore-575025, Karnataka, India \\ ${ }^{2}$ Department of Thermal and Energy Engineering, VIT University, Vellore-632014, Tamilnadu, India.
}

\begin{abstract}
Glass is the major component of the building envelope to provide visual comfort to inside the buildings. In général clear and bronze glass was used as a main building envelope for both residential and commercial buildings to provide better day lighting into the buildings. If we use more glass area as a building envelope more radiation allows into the buildings. So that it is necessary to reduce more solar radiation and provide sufficient daylight factor inside the building's through glass windows with the help of external devices called shading devices. In this work four shading devices was tried on bronze glass window to find the heat gain and daylighting into buildings. This paper presents the experimental measurement of spectral characteristics of bronze glass which include transmission and reflection in entire solar spectrum region $(300 \mathrm{~nm}-$ $2500 \mathrm{~nm}$ ) based on ASTM standards. A MATLAB code was developed to compute visible and solar optical properties as per the British standards. A building model was designed by design builder software tool. $40 \%$ window to wall ratio was considered for building models, thermal and day lighting analysis of buildings through windows was carried out in Energy plus software tool for hot and dry climatic zone of India.
\end{abstract}

Keywords: Bronze glass window, spectral characteristics, spectrophotometer, design builder, adequate day light factor and external shading devices

\section{Introduction}

Now a day's glass is used as main building envelope material to construct the buildings for providing visual comfort from inside to outside the occupants. Especially most of the commercial buildings are used different glasses like clear and bronze as main building envelopes. Due to usage of more quantity of glasses to allow direct solar radiation and high percentage of day lighting so that more heat gain and comfortable conditions will not occur into buildings because due to their visible and solar optical properties. So that we need

\footnotetext{
*Corresponding author: gorantla.kirankumar@gmail.com
} 
external devices to allow minimum solar radiation and as well as sufficient day lighting into buildings and provide thermal comfort to the occupants, such devices call external shading devices. External devices are classified as mainly four types overhang, louvers with different orientations, egg-crate shading and (egg-crate + louver) shading devices.

Previous authors have worked on different external shading devices on various glass materials to reduce the direct solar radiation into buildings. To study the various shading devices vertical fins, overhangs and egg-crate windows find the best shading device to Jordan University of science and technology administration office buildings in south-west façade orientation to control the direct solar radiation and improve the visual comfort and protect glare by using various simulation software's IES/Sun-Cast and Radiance to analyzed annually and compared with experimental results in detail [1]. By arranging different slant lengths, tilts of fixed horizontal louver shading devices on window glasses and analyzing the thermal performance of these buildings by using TRNSYS simulation of four climatic regions in Italy it was found that $70 \%$ decrease of solar radiation in summer and $40 \%$ increase in winter seasons has been reported annually [2]. To decrease the direct solar radiation through various louver shading areas arranged on windows to various climatic zones of different countries in European continent by considering horizontal and vertical louver shadow geometry were analyzed by energy equation solver to save the power consumption by using TRNSYS simulation software annually were reported in literature [3]. Detailed study of roller blinds and venetian blinds of shading device models developed and numerically found the solar and visible properties of total fenestration systems, finally suggests that venetian blinds results better than roller blinds when experimented to reduce the solar radiation and improved the day light illuminance levels in both clear and overcast sky conditions of Lisbon latitude climatic region in Portugal country [4]. By using building energy performance simulations software between past and present on shading devices and comparing to various selected solar position on different shading devices resulted an error in present has been described in detail at Algeciras latitude climatic region [5]. To decreases heat losses from the windows in winter season Poznan latitude climatic region of Poland country to analyze the air temperature, wind effect on double glazed windows with an air gap $20 \mathrm{~mm}$ and also tried with internal and external roller blinds save the power nearly $29 \%$ to $44 \%$ in Central European continent studied in detail [6]. To find out the interior day light illuminanace levels from the double clear glass window at different points in a room and analyze day lighting performance assessment algorithms radiosity and split-flux methods with DE light and Energy simulation programs comparing and validated experimentally in detail [7].

To find the inside day light illuminance levels of building model with south oriented clear glass window and analyzed on other orientations such as north, east and west comparative study of two day lighting analysis methods with regard to window orientation and interior all reflectance [8]. To study of various double glazing windows like clear, bronze and low E-glasses to keep the windows as building envelopes and find the best suitable window reduce the electric energy consumption Dhahran latitude hot climatic region in Saudi Arabia was done by [9]. Find the total solar energy transmittance of glazing with venetian blind shading of different geometries to keep the laboratory applied physics measure the global solar radiation experimentally and numerically validated to near Zurich latitude climatic region Switzerland country in detail [10]. A numerical and analytical method was developed to keep the egg-crate shading devices on vertical windows of arbitrary orientation to reduce solar radiation Venice and Bologna latitudes climatic regions to Italy country was studied in detail [11].

To determine the simplified procedure i.e. using nomographs and waldram diagrams establish and described to find indoor daylight illuminance using daylight coefficient 
concept to university of building and construction of university of Hong Kong was reported in detail [12].

To find the day light illuminance levels on horizontal plane of an office building room with a controlled shading device of double glazing window with internal blinds and control glare levels and provide adequate daylight factor inside the buildings from different points from window was reported by [13]. Daylight factor model was developed under clear sky conditions in east oriented window and experimentally validated to New Delhi climatic region and find out the daylight illuminanace levels of windows high and bottom to keep the building walls in south and north oriented windows at different sky conditions was reported in [14]. The main objective of the present work is reduce the most of the solar radiation by keeping various external shading devices on bronze glass windows and also provide adequate daylight factor inside the buildings of hot $\&$ dry climatic region (Jodhpur) in India.

\section{Experimental procedure to measure the spectral characteristics of bronze glass window}

Perkin Elmer Lambda 950 spectrophotometer is an UV-VIS-NIR instrument used to measure the spectral characteristics of glass windows. For measuring the spectral characteristics of glass sample is keeping vertical i.e. normal angle of incidence $\left(90^{\circ}\right.$ from horizontal) wavelength range from $(300 \mathrm{~nm}-2500 \mathrm{~nm})$ based on ASTM Standards [15]. To find the visible properties to measure wavelength range from $(380 \mathrm{~nm}-780 \mathrm{~nm})$ and solar optical properties to measure from wavelength range $300 \mathrm{~nm}$ to $2500 \mathrm{~nm}$ which is obtained from the measured spectral characteristics data as shown in Figure 1. Solar heat gain coefficient factor is an important factor to find the solar radiation passing through window glass. A MATLAB code was developed to compute the solar optical properties like transmittance, reflectance in entire solar spectrum region $(300 \mathrm{~nm}-2500 \mathrm{~nm})$ by using equations 1, 2 and 3 based on British standards [16,17].

$$
\begin{aligned}
& T_{\text {Sol }}=\sum_{\lambda=100}^{\lambda=2500} S_{\lambda} \tau(\lambda) \Delta \lambda / \sum_{\lambda=\pi 00}^{\lambda=2500} S_{\lambda} \Delta \lambda \\
& R_{\text {Sol }}=\sum_{\lambda=100}^{\lambda=2500} S_{\lambda} \rho(\lambda) \Delta \lambda / \sum_{\lambda=a 00}^{\lambda=2500} S_{\lambda} \Delta \lambda
\end{aligned}
$$

Solar absorbance of the glass window can be found by knowing the solar transmittance and reflectance

$$
A_{\text {Sol }}=100-T_{\text {Sol }}-R_{\text {Sol }}
$$

To find the day light factor inside the buildings through windows it is necessary to measure the spectral data of glass windows from wavelength range $380 \mathrm{~nm}$ to $780 \mathrm{~nm}$ at normal angle of incidence. A MATLAB code was developed to compute the visible properties like transmittance, reflectance in the visible spectrum region $(380 \mathrm{~nm}-780 \mathrm{~nm})$ by using equations 5, 6 and 7 based on British standards. Daylight factor is defined as the ratio of indoor illumination to outdoor illumination available in outside the building. Units of day light factor is in (\%) or in (Lux).

$$
D F=\frac{E i}{E o} \times 100 \%
$$


The day lighting strategies not only reduce lighting energy use but they are also responsible for an increase in cooling/heating loads. Table 1 shows the visible, solar optical properties and solar heat gain coefficient of bronze glass window.

$$
\begin{aligned}
& T_{\text {Vis }}=\sum_{\lambda=380}^{\lambda=780} D_{\lambda} \tau(\lambda) V(\lambda) \Delta \lambda / \sum_{\lambda=380}^{\lambda=780} D_{\lambda} V(\lambda) \Delta \lambda \\
& R_{\text {Vis }}=\sum_{\lambda=\pi 80}^{\lambda=780} D_{\lambda} \rho(\lambda) V(\lambda) \Delta \lambda / \sum_{\lambda=\pi 80}^{\lambda=780} D_{\lambda} V(\lambda) \Delta \lambda
\end{aligned}
$$

Visible absorbance of the glass window can be found by knowing the visible transmittance and reflectance of the glass window.

Table 1. Visible, solar optical properties and solar heat gain coefficient of bronze window glass of thickness $6 \mathrm{~mm}$.

\begin{tabular}{|c|c|c|c|c|c|c|c|}
\hline & \multicolumn{3}{|c|}{ Visible spectrum $(380 \mathrm{~nm}-$} & \multicolumn{3}{c|}{ Total solar spectrum (300nm- } & \\
\hline Window glass & $\mathrm{T}_{\text {Wis }}(\%)$ & $\mathrm{R}_{\text {Wis }}(\%)$ & $\mathrm{A}_{\text {Wis }}(\%)$ & $\mathrm{T}_{\text {Sol }}(\%)$ & $\mathrm{R}_{\text {Sol }}(\%)$ & $\mathrm{A}_{\text {Sol }}(\%)$ & $\mathrm{SHGC}(\%)$ \\
\hline Bronze glass window & 50 & 6 & 44 & 49 & 6 & 45 & 62 \\
\hline
\end{tabular}

$$
A_{\text {Vis }}=100-T_{\text {Vis }}-R_{\text {Vis }}
$$

Figure 1 (a) shows the spectral characteristics of bronze glass window in UV-VIS spectrum region and figure 1 (b) shows the spectral characteristics of bronze glass window in entire solar spectrum region. These properties are very important to find the solar optical properties of glass windows like transmittance and reflectance to calculate the solar heat gain coefficient of the window glass and also to find the total solar radiation through glass windows into the buildings.

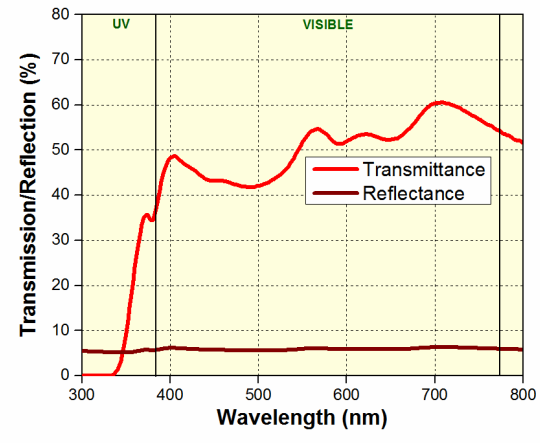

(a)

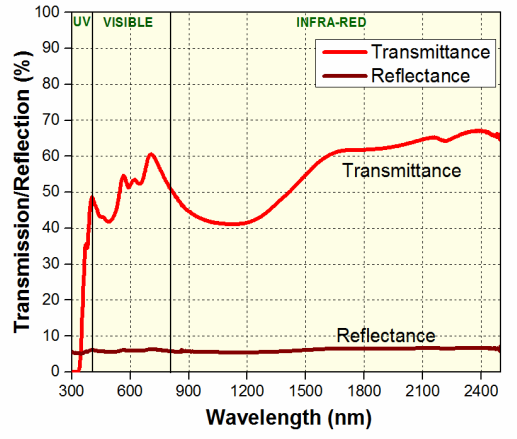

(b)

Fig. 1. Spectral transmission and reflection of bronze glass window (a) UV-VIS spectrum region (b) Solar spectrum region

\section{Design and simulation methodology}

In this work reading room building model was designed with $4 \mathrm{~m} \times 4 \mathrm{~m} \times 4 \mathrm{~m}$ dimensions by using design builder 4.3.0.039 version tool. Building external walls designed by laterite wall of thickness $0.2 \mathrm{~m}$ and cement plaster was added on both sides of the wall thickness 
$0.0125 \mathrm{~m}$. Roof of the building material was designed by reinforced cement concrete of thickness $0.150 \mathrm{~m}$ and cement plaster was added on top and bottom sides of the roof of thickness $0.0125 \mathrm{~m}$. Floors of the building model were designed by dense concrete of thickness $0.150 \mathrm{~m}$ and cement plaster was added on top side of the floor of thickness $0.0125 \mathrm{~m} .40 \%$ window to wall ratio was considered as per Indian standards [18], window of dimensions $3.2 \mathrm{mX} 2 \mathrm{~m}$ is keeping in all orientations like east, west, north and south and also keeping various shading devices like $0.5 \mathrm{~m}$ overhang, $0.5 \mathrm{~m}$ louver thickness $0.020 \mathrm{~m}$ of five quantity, $0.5 \mathrm{~m}$ Egg-crate window and $(0.5 \mathrm{~m}$ Egg-crate $+0.5 \mathrm{~m}$ Louver) on windows of thickness is $5 \mathrm{~mm}$ and quantity 5 keep spacing between plates is $0.400 \mathrm{~m}$, of four type was keeping one by one like that total sixteen building models were analyzed in four orientations. In this work find the solar radiation gain into the buildings through windows to hot and dry climatic region Jodhpur at summer solstice and also at winter solstice was done as per Indian standards [19-20]. As per Indian standards for reading room recommended daylight factor is in between $1.9 \%$ to $3.75 \%$ [21]. To find the average daylight factor levels inside the building were computed at a height of $0.75 \mathrm{~m}$ from the floor by using split-flux algorithm as per International Commission on Illumination standards (CIE Standards) in both summer and winter seasons by using Energy plus 8.1.0.009 version tool from morning 9:00 hrs to 16:00 hrs. Figure 2 shows the building model of dimensions $4 \mathrm{mx} 4 \mathrm{mx} 4 \mathrm{~m}$ and window of $3.2 \mathrm{mX} 2 \mathrm{~m}$ window size four shading devices namely overhang $0.5 \mathrm{~m}, 0.5 \mathrm{~m}$ Louvers, $0.5 \mathrm{~m}$ Egg-crate and $(0.5 \mathrm{~m}$ Egg-crate $+0.5 \mathrm{~m}$ Louvers $)$ arranged.

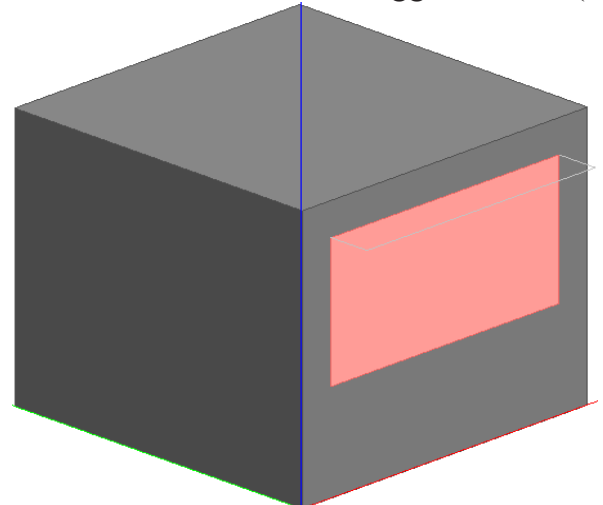

(a)

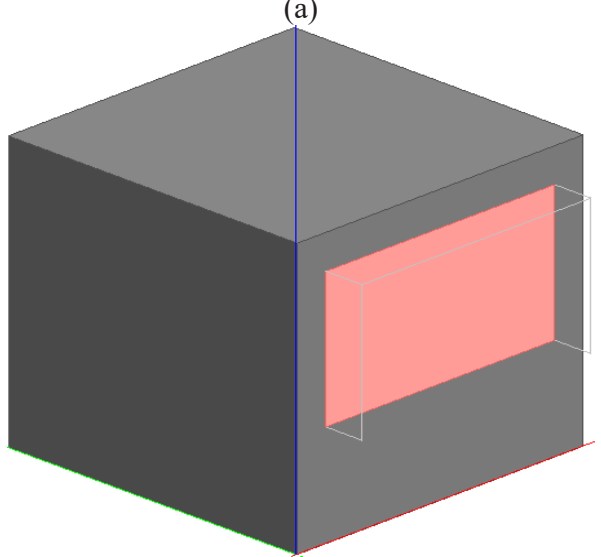

(c)

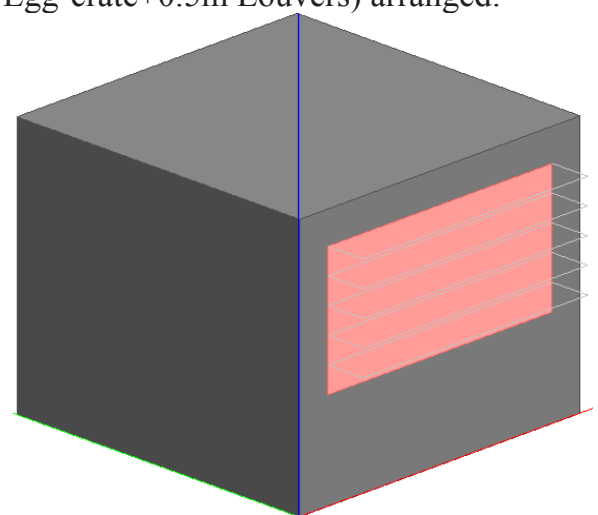

(b)

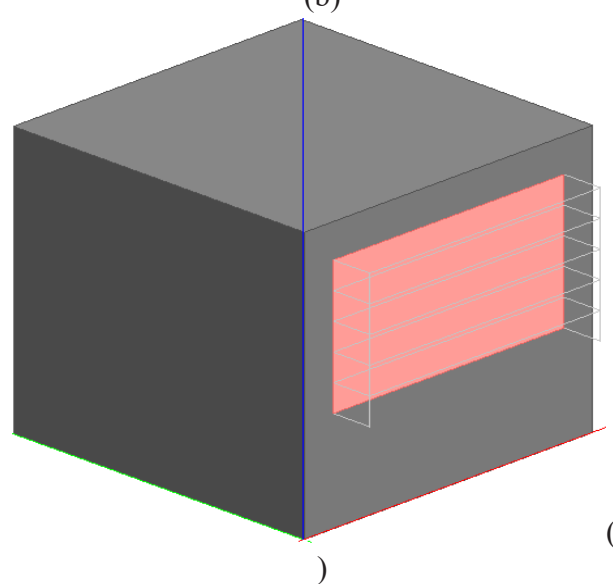

Fig. 2. Building model of dimensions $4 \mathrm{~m} \times 4 \mathrm{~m} \times 4 \mathrm{~m}$ with external shading devices (a) Overhang shading device; (b) Louver shading device; (c) Egg-crate shading device; (d) (Egg-crate $0.5 \mathrm{~m}+0.5 \mathrm{~m}$ Louver) shading device. 


\section{Results and discussions}

\subsection{Solar radiation gain into buildings through various shading devices on bronze glass window to Jodhpur (Hot \& Dry) climatic region in summer and winter season}

Figure 3 (a) and Figure 3 (b) shows the solar radiation passing through different shading devices on bronze glass windows from four directions like east, west, north and south on windows to Jodhpur $\left(26.30^{\circ} \mathrm{N}, 77.58^{\circ} \mathrm{E}\right)$ climatic region at summer solstice and at winter solstice as per Indian standards. From the graphs it is clearly observed that the solar radiation gain into the buildings through all four types of shading devices on windows from west orientation is more and less in south orientation in summer season, and also clearly observed that the solar radiation gain into the buildings through all four types of shading devices on windows from south orientation is more and less in north orientation in winter season. In summer season at peak summer day June $21^{\text {st }}$ in south direction solar radiation gain into buildings with $(0.5 \mathrm{~m}$ Egg-crate $+0.5 \mathrm{~m}$ Louver) shading device is gaining less heat $2.79 \mathrm{kWh}$ when compared to all other shading devices. In winter season at peak summer day June $21^{\text {st }}$ in south direction solar radiation gain into buildings with $0.5 \mathrm{~m}$ shading device is gaining more heat $11.01 \mathrm{kWh}$, when compared to all other shading devices. For this work Energy plus 8.1.0.009 version tool used to find the day lighting, this software gives average daylight factor inside the buildings in percentages at a distance from $0.75 \mathrm{~m}$ from the floor.

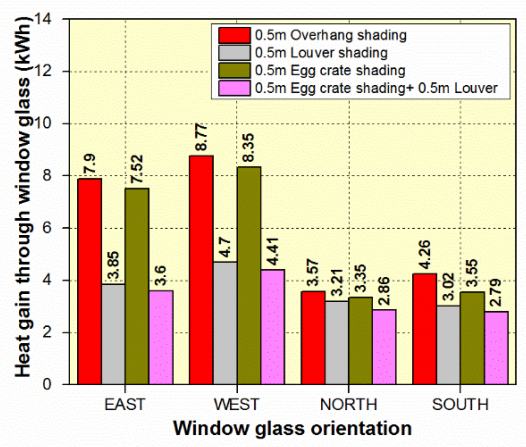

(a)

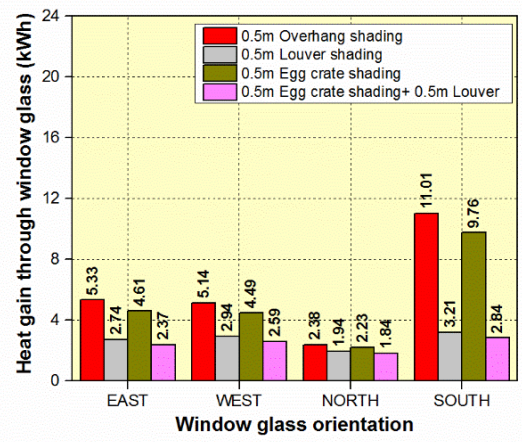

(b)

Fig. 3. Heat gain into buildings through different external shading devices to Jodhpur climatic region (a) Summer season; (b) Winter season.

\subsubsection{Effect of $0.5 \mathrm{~m}$ overhang shading device on windows for average daylight factor into buildings in both summer and winter seasons of Jodhpur (Hot \& Dry) climatic region}

From Figure 4 (a) to Figure 4 (d) shows the Average daylight factor in an laboratory building at a height of $0.75 \mathrm{~m}$ from the floor with bronze glazing window placed in East, West, North and South orientation at peak summer day (June $21^{\text {st }}$ ) and peak winter day (December $21^{\text {st }}$ ) of Jodhpur city (Hot and dry climatic zone) as per CIE standards from morning 9:00 hrs to 16:00 hrs. From Figures, it is observed that daylight factor in buildings in east orientation window is decreasing with time in both summer and winter seasons. It is also noticed that the daylight factor in buildings in west orientation window increases with 
the increase in time during both summer and winter seasons. Average daylight factor in summer season is dropped during 13:00 hrs in all orientations i.e. because sun is at zenith position and sun moves from zenith to west orientation and also sky illumination (Clear sky) available at that time. Average daylight factor in winter season is coming curve shape i.e. because sky illumination (Overcast sky) available at that time and day. In north orientation, average daylight factor is periodic during summer as shown in Figure 4 (c) that is due to sun travels from northeast to northwest orientation and also depends on sky illumination available outside at that particular day and time. In winter, average daylight factor is look like parabola as shown in Figure 4 (c) that is due to that is due to sun travels from southeast to southwest orientation and also sky illumination is available outside at that particular day and time. In south orientation, the average daylight factor is periodic during summer as shown in Figure 4 (c) that is due to sun travels from northeast to northwest orientation and also depends on sky illumination available outside at that particular day and time as shown in Figure 4 (d) during summer season as shown in Figure 4 (d). In winter, average daylight factor is look like parabola as shown in Figure 4 (c) that is due to that is due to sun travels from southeast to southwest orientation and also sky illumination is available outside at that particular day and time.

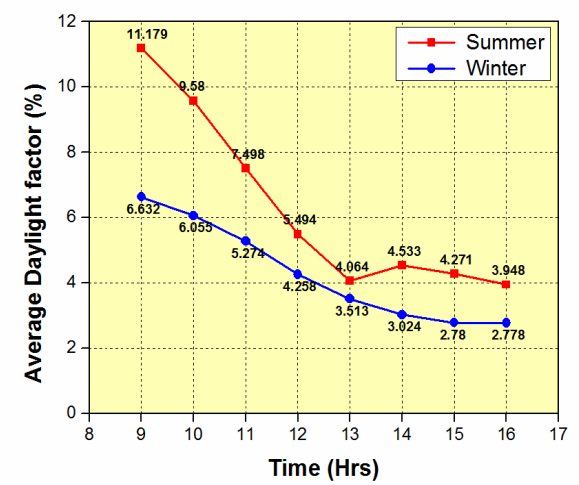

(a)

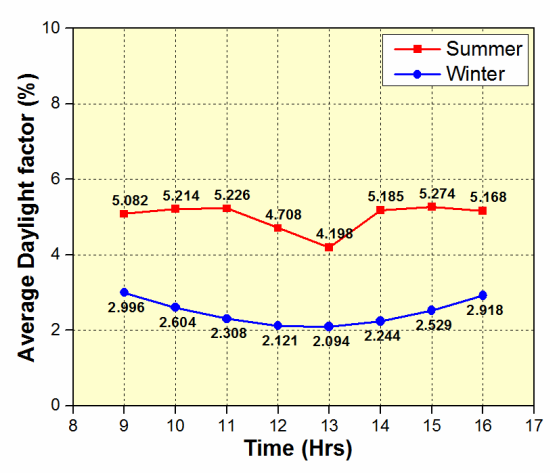

(c)

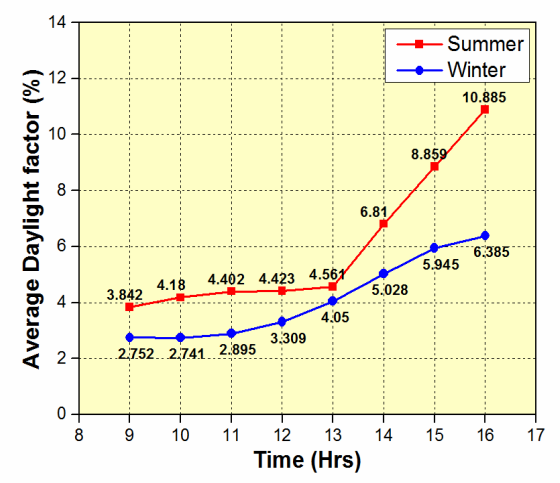

(b)

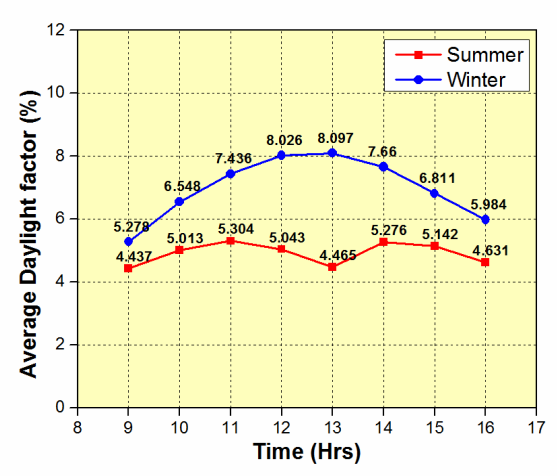

(d)

Fig. 4. Average daylight factor into buildings through $0.5 \mathrm{~m}$ overhang shading device on bronze glass window (a) East direction (b) West direction (c) North direction and (d) South direction. 


\subsubsection{Effect of $0.5 \mathrm{~m}$ louver shading device on windows for average daylight into buildings in both summer and winter season to Jodhpur (Hot \& Dry) climatic region}

From Figure 5 (a) to Figure 5 (d) shows the Average daylight factor in an laboratory building at a height of $0.75 \mathrm{~m}$ from the floor with bronze glazing window placed in East, West, North and South orientation at peak summer day (June $21^{\text {st }}$ ) and peak winter day (December $21^{\text {st }}$ ) of Jodhpur city (Hot and dry climatic zone) as per CIE standards from morning 9:00 hrs to 16:00 hrs. From Figures, it is observed that daylight factor in buildings in east orientation window is decreasing with time in both summer and winter seasons. It is also noticed that the daylight factor in buildings in west orientation window increases with increase time during both summer and winter seasons. In north orientation, average daylight factor is periodic during summer as shown in Figure 5 (c) that is due to sun travels from northeast to northwest orientation and also depends on sky illumination available outside at that particular day and time. In winter, average daylight factor is look like parabola as shown in Figure 5 (c) that is due to that is due to sun travels from southeast to southwest orientation and also sky illumination is available outside at that particular day and time. In south orientation, the average daylight factor is periodic during summer as shown in Figure 5 (c) that is due to sun travels from northeast to northwest orientation and also depends on sky illumination available outside at that particular day and time as shown in Figure 5 (d) during summer season as shown in Figure 5 (d). In winter, average daylight factor is look like parabola as shown in Figure 5 (c) that is due to that is due to sun travels from southeast to southwest orientation and also sky illumination is available outside at that particular day and time.

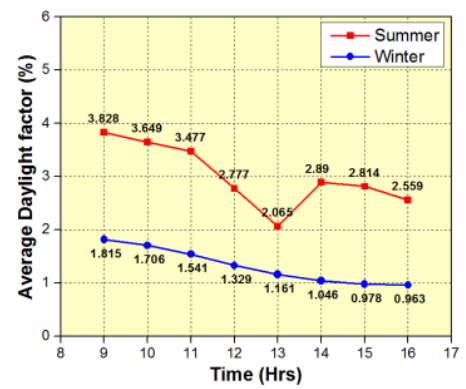

(a)

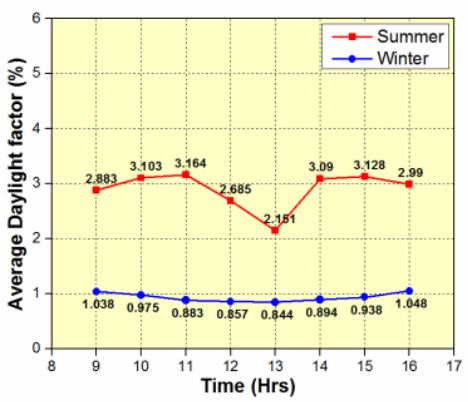

(c)

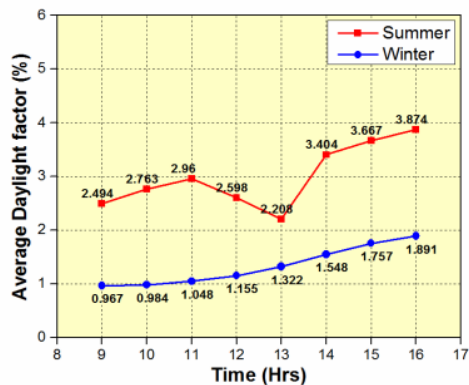

(b)

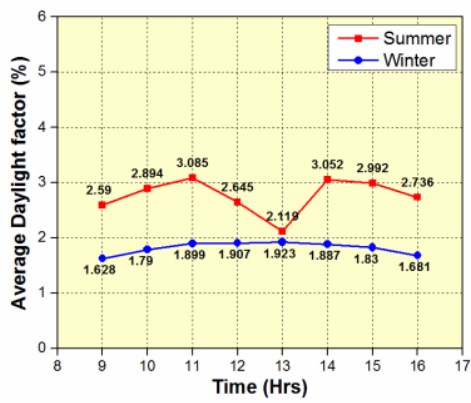

(d)

Fig. 5. Average daylight factor into buildings through $0.5 \mathrm{~m}$ louver shading device on bronze glass window (a) East direction (b) West direction (c) North direction and (d) South direction. 


\subsubsection{Effect of $0.5 \mathrm{~m}$ Egg-crate shading device on windows for average daylight into buildings in both summer and winter season to Jodhpur (Hot \& Dry) climatic region}

From Figure 6 (a) to Figure 6 (d) shows the Average daylight factor in an laboratory building at a height of $0.75 \mathrm{~m}$ from the floor with bronze glazing window placed in East, West, North and South orientation at peak summer day (June $21^{\text {st }}$ ) and peak winter day (December $21^{\text {st }}$ ) of Jodhpur city (Hot and dry climatic zone) as per CIE standards from morning 9:00 hrs to 16:00 hrs. From Figures, it is observed that daylight factor in buildings in east orientation window is decreasing with time in both summer and winter seasons. It is also noticed that the daylight factor in buildings in west orientation window increases with increase time during both summer and winter seasons. In north orientation, average daylight factor is periodic during summer as shown in Figure 6 (c) that is due to sun travels from northeast to northwest orientation and also depends on sky illumination available outside at that particular day and time. In winter, average daylight factor is look like parabola as shown in Figure 6 (c) that is due to that is due to sun travels from southeast to southwest orientation and also sky illumination is available outside at that particular day and time. In south orientation, the average daylight factor is periodic during summer as shown in Figure 6 (c) that is due to sun travels from northeast to northwest orientation and also depends on sky illumination available outside at that particular day and time as shown in Figure 6 (d) during summer season as shown in Figure 6 (d). In winter, average daylight factor is look like parabola as shown in Figure 6 (c) that is due to that is due to sun travels from southeast to southwest orientation and also sky illumination is available outside at that particular day and time.

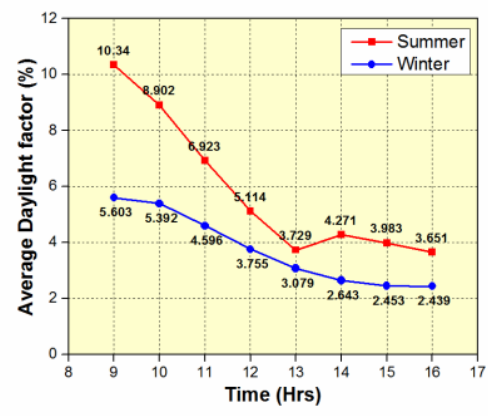

(a)

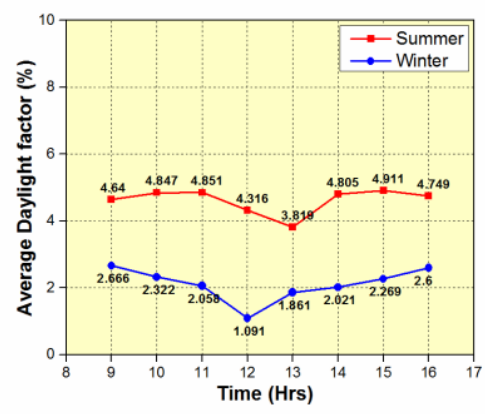

(c)

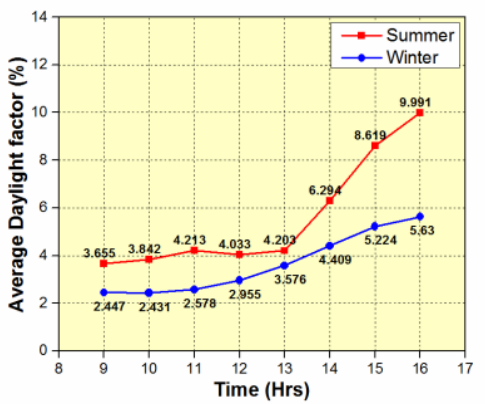

(b)

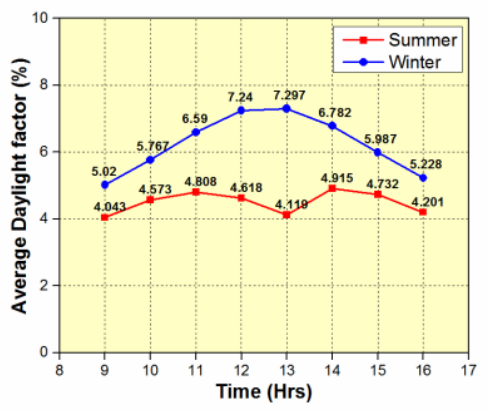

(d)

Fig. 6. Average daylight factor into buildings through $0.5 \mathrm{~m}$ Egg-crate shading device on bronze glass window (a) East direction (b) West direction (c) North direction and (d) South direction. 
4.1.4 Effect of (0.5m Egg-crate $+0.5 m$ Louvers) shading device on windows for average daylight into buildings in both summer and winter season to Jodhpur (Hot \& Dry) climatic region

From Figure 7 (a) to Figure 7 (d) shows the Average daylight factor in an laboratory building at a height of $0.75 \mathrm{~m}$ from the floor with bronze glazing window placed in East, West, North and South orientation at peak summer day (June $21^{\text {st }}$ ) and peak winter day (December $21^{\text {st }}$ ) of Jodhpur city (Hot and dry climatic zone) as per CIE standards from morning 9:00 hrs to 16:00 hrs. From Figures, it is observed that daylight factor in buildings in east orientation window is decreasing with time in both summer and winter seasons. It is also noticed that the daylight factor in buildings in west orientation window increases with increase time during both summer and winter seasons.

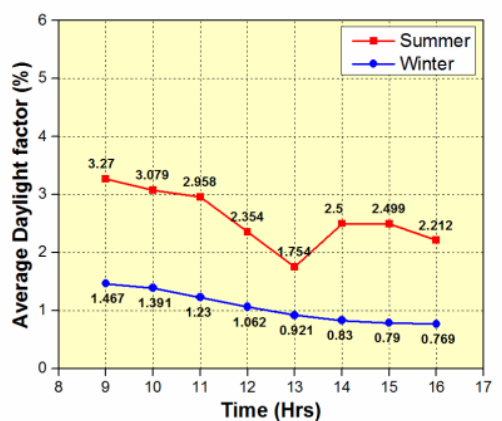

(a)

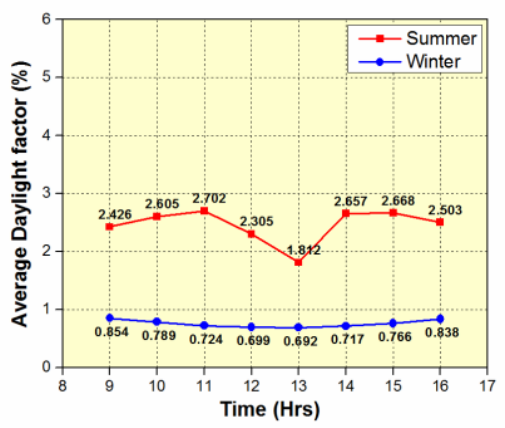

(c)

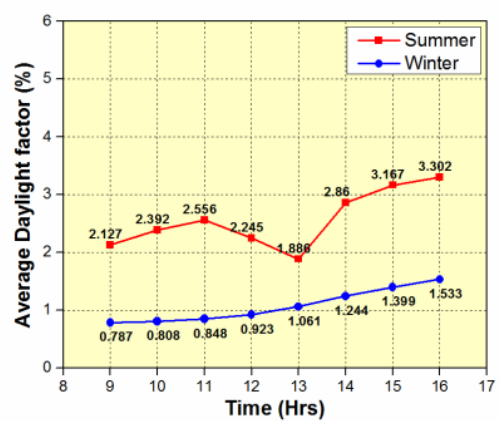

(b)

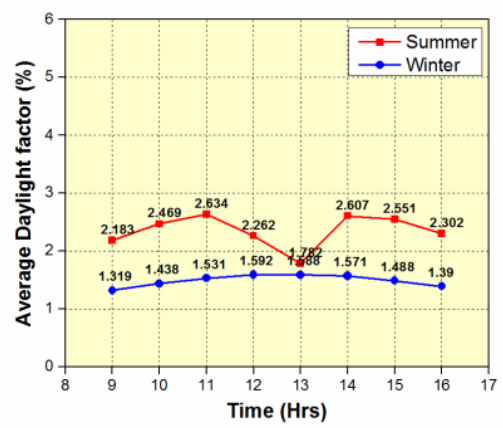

(d)

Fig. 7. Average daylight factor into buildings through $(0.5 \mathrm{~m}$ Egg-crate $+0.5 \mathrm{mSide}$ fins $)$ shading device on bronze glass window (a) East direction; (b) West direction; (c) North direction and (d) South direction.

In north orientation, average daylight factor is periodic during summer as shown in Figure 7 (c) that is due to sun travels from northeast to northwest orientation and also depends on sky illumination available outside at that particular day and time. In winter, average daylight factor is look like parabola as shown in Figure 7 (c) that is due to that is due to sun travels from southeast to southwest orientation and also sky illumination is available outside at that particular day and time. In south orientation, the average daylight factor is periodic during summer as shown in Figure 7 (c) that is due to sun travels from northeast to northwest orientation and also depends on sky illumination available outside at that particular day and time as shown in Figure 7 (d) during summer season as shown in Figure 
7 (d). In winter, average daylight factor is look like parabola as shown in Figure 7 (c) that is due to that is due to sun travels from southeast to southwest orientation and also sky illumination is available outside at that particular day and time.

\begin{tabular}{|c|c|c|}
\hline \multicolumn{2}{|c|}{ Nomenclature } & $\Delta \lambda \quad$ Wavelength interval (nm) \\
\hline$A_{\text {Vis }}$ & Visible absorbance $(\%)$ & $\begin{array}{l}\mathrm{D}_{\lambda} \quad \text { Relative spectral distribution of illuminant D65 } \\
\text { (Dimensionless) }\end{array}$ \\
\hline $\mathrm{A}_{\mathrm{Sol}}$ & Solar absorbance $(\%)$ & $\begin{array}{l}V(\lambda) \text { Spectral luminous efficiency for photopic vision defining } \\
\text { the standard observer for photometry (Dimensionless) }\end{array}$ \\
\hline $\mathbf{R}_{\text {V15 }}$ & Visible reflectance $(\%)$ & (a) Spectral transmission $(\%)$ \\
\hline $\mathbf{R}_{\text {Sol }}$ & Solar reflectance $(\%)$ & $p(\lambda)$ Spectral reflection $(\%)$ \\
\hline $\begin{array}{l}T_{\text {Vis }} \\
(\%)\end{array}$ & Visible transmittance & $\alpha(\lambda)$ Spectral absorption (\%) \\
\hline $\begin{array}{l}\mathrm{T}_{\text {Sol }} \\
\text { Greek }\end{array}$ & $\begin{array}{l}\text { Solar transmittance }(\%) \\
\text { letters }\end{array}$ & Relative spectral distribution of the solar radiation $\left(\mathrm{W} / \mathrm{m}^{2}\right)$ \\
\hline$\lambda$ & Wavelength $(\mathrm{nm})$ & \\
\hline
\end{tabular}

\section{Conclusions}

The present work presents the reduce solar radiation passing through different shading devices on bronze glass window as well as provide adequate day light factor into buildings in four orientations of hot and dry climatic region (Jodhpur), in both summer and winter seasons.

- In Summer season south orientation window having $(0.5 \mathrm{~m}$ Egg-crate $+0.5 \mathrm{~m}$ Louver) shading device, heat gain inside the building is less $(2.84 \mathrm{kWh})$ compared to all other directions and shading devices and also provide adequate day light factor into reading room $(2.183 \%$ to $2.302 \%)$ of hot \& dry climatic zone in India.

- In winter season south orientation window having $0.5 \mathrm{~m}$ overhang shading device on window, heat gain inside the building is more $(11.01 \mathrm{kWh})$ compared to all other directions and shading devices, as far as daylight is concerned adequate day light factor into reading room is $(2.996 \%$ to $2.918 \%)$ in north orientation is preferable to hot \& dry climatic zone of India.

\section{References}

1. A. Ahmed, Y. Freewan, Sol. Energy, 102, 14-30, (2014)

2. D. Gouri, Renew. Energy, 23, 497-507, (2001)

3. I. Ana, M. Palmero, CO. Armando, Appl. Energy, 87, 2040-2049, (2010)

4. M. Gloria Gomes, A.J. Santos, A. Moret Rodrigues, Build. Environ. 71, 47-59, (2014)

5. R.M. Ismael, F.B. Juan Luis, G.G. Francisco Javier, R.C. Paloma, Energ. Build. 101, 144-152, (2015)

6. OP. Czeslaw, S. Marta, Energ. Build. 73, 48-58, (2014)

7. B.Y. Yeo, R.J. Woo, H.L. Kwang, Energies, 7, 2362-2376, (2014)

8. B.Y. Yeo, M. Rashmi, and H.L. Kwang. Energies, 7, 2362-2376, (2014)

9. A.F. Mohammed and M.B. Ismail, Energ. Build. 108, 307-316, (2015)

10. S. Hans and B. Bruno, Build. Environ. 43, 197-204, (2008)

11. S, Giovanni and Barozzi, Solar Energy, 39(4), 329-342 (1987) 
12. H.W.Li, Danny, H.W.C, Gary and C.S.L. Chris. Build. Environ. 41, 578-589 (2006)

13. A.K. Athienitis and A. Tzempelikos, Sol. Energy, 72(4), 271-281, (2002)

14. Su. Madhu, G.N. Tiwari, and I.M. Al-Helal. Sol. Energy, 115, 379-389, (2015)

15. ASTM E424 Test for Solar energy Transmittance and Reflectance (terrestrial) of sheet materials Washington DC, USA. (1971)

16. BS EN 410 Glass in Building-Determination of luminous and solar characteristics of the glazing British Standards, (1998)

17. ISO 9050:2003(E), Glass in building-Determination of light transmittance, solar direct transmittance, total solar energy transmittance, ultraviolet transmittance and related glazing factors (2003)

18. ECBC, Energy Conservation Building Code. Bureau of Energy Efficiency, New Delhi, India (2009)

19. NBC National Building Code of India 2005, Section 1 Building and Services Lighting and Ventilation Part-I, Bureau of Indian Standards, New Delhi, India. (2005)

20. A. Mani, Solar radiation over India Allied Publishers private limited, India. (1982)

21. SP: 41. (S\&T) Handbook on functional Requirement of Buildings other than industrial buildings. Bureau of Indian Standards, India. (1987) 